\title{
DETEKSI AWAL HABITAT PERAIRAN LAUT DANGKAL MENGGUNAKAN TEKNIK OPTIMUM INDEX FACTOR PADA CITRA SPOT 7 DAN LANDSAT 8
}

\author{
Anang Dwi Purwanto, Kuncoro Teguh Setiawan \\ Pusat Pemanfaatan Penginderaan Jauh, Lembaga Penerbangan dan \\ Antariksa Nasional, Jakarta Timur, Indonesia \\ E-mail: anang_depe@yahoo.com
}

Received June 2019, Accepted September 2019

\begin{abstract}
ABSTRAK
Informasi keberadaan habitat perairan laut dangkal semakin dibutuhkan terutama dalam kegiatan pelestarian lingkungan dan monitoring di wilayah pesisir. Komponen penyusun ekosistem habitat dasar perairan laut dangkal di antaranya terumbu karang dan lamun dimana lokasi keberadaan obyek habitat ini cenderung berdekatan. Dalam interpretasi ekosistem habitat dasar perairan laut dangkal terkendala oleh lokasi keberadaan ekosistem yang berasosiasi dengan obyek lainnya. Tujuan penelitian ini adalah menentukan kombinasi komposit kanal terbaik dalam mengidentifikasi obyek habitat dasar perairan laut dangkal di Pantai Pemuteran, Bali. Data citra satelit yang digunakan dalam penelitian ini adalah citra SPOT 7 akuisisi tanggal 11 April 2018 dan citra Landsat 8 akuisisi tanggal 14 April 2018, sedangkan data terkait informasi sebaran habitat dasar perairan laut dangkal diperoleh berdasarkan hasil survei lapangan yang telah dilakukan pada tanggal 7-13 April 2018 di Pantai Pemuteran, Bali. Data citra satelit diperoleh dari Pusat Teknologi dan Data LAPAN. Untuk menentukan kombinasi dari 3 (tiga) kanal terbaik dalam interpretasi habitat dasar perairan laut dangkal digunakan metode Optimum Index Factor (OIF) dimana metode ini menggunakan nilai standar deviasi dan koefisien korelasi dari kombinasi 3 (tiga) kanal citra yang digunakan. Hasil penelitian menunjukkan kombinasi komposit 2 (hijau), 3 (merah) dan 4 (NIR) mempunyai nilai OIF tertinggi untuk citra SPOT 7, sedangkan kombinasi komposit 2 (biru), 4 (merah) dan 6 (SWIR 1) Mempunyai nilai OIF tertinggi untuk citra Landsat 8. Interpretasi sebaran habitat dasar perairan laut dangkal dapat dilakukan secara efektif
\end{abstract}


dengan menggunakan citra komposit RGB 423 untuk citra SPOT 7 dan RGB 642 untuk citra Landsat 8.

Kata Kunci : Perairan Dangkal, Habitat, OIF, SPOT 7, Landsat 8, Pemuteran

\section{ABSTRACT}

\section{DETECTION OF SHALLOW WATER HABITATS USING OPTIMUM INDEX FACTORS TECHNIQUE ON SPOT 7 AND LANDSAT 8} IMAGERY. Information of the existence of the shallow water habitat is required especially in environmental conservation and monitoring of activities in coastal areas. The component of the shallow water habitat including coral reefs and seagrass where the location of the existence of these relatively close together. Interpretation of the shallow water habitat is constrained by the location of ecosystem associated with other objects. The aim of study is to determine the best combination of band composites in identifying the shallow water habitat in Pemuteran Beach, Bali. The study used SPOT 7 imagery (acquisition on April 11, 2018) and Landsat 8 imagery (acquisition on April 14, 2018). The data of the shallow water habitat based on the result of field survey was conducted on 7-13 April 2018 at Pemuteran Beach, Bali. Image data obtained from Remote Sensing Technology and Data Center of LAPAN. Determination of combination of 3 (three) bands the shallow water habitat using Optimum Index Factor (OIF) method where this method used standard deviation value and correlation coefficient from combination of 3 (three) bands. The results show the composite combinations of band 2 (green), band 3 (red) and band 4 (NIR) have the highest OIF values for SPOT 7 image, while the composite combinations of band 2 (blue), band 4 (red) and band 6 (SWIR 1) have the highest OIF values for Landsat 8 image. Interpretation of distribution of shallow water habitat can be done effectively using RGB 423 composite image (SPOT 7) and RGB 642 composite image (Landsat 8).

Keywords : Shallow Water, Habitat, OIF, SPOT 7, Landsat 8,Pemuteran

\section{PENDAHULUAN}

Ekosistem pesisir yang banyak dijumpai di wilayah perairan adalah terumbu karang dan lamun. Kedua ekosistem (terumbu karang dan lamun) merupakan komponen utama sebagai penyusun ekosistem di perairan laut dangkal dimana dalam lingkup penginderaan jauh batasan istilah perairan laut dangkal merujuk pada kemampuan citra satelit dalam menembus kolom perairan (Setyawan et al., 2014). Indonesia mempunyai kekayaan dan keanekaragaman hayati terbesar di dunia dimana salah satunya adalah ekosistem terumbu karang. Indonesia juga memiliki 
panjang garis pantai lebih dari $81.000 \mathrm{Km}$ dan didukung dengan lebih dari 17.508 pulau serta luas laut sekitar 3,1 juta $\mathrm{Km}^{2}$ (Dahuri et al., 1996 dalam Dewi, 2006). Keberadaan ekosistem terumbu karang dan lamun memiliki peranan penting bagi manusia dan lingkungan di sekitarnya sehingga kekayaan hayati tersebut hendaknya senantiasa terjaga dan terlindung dari semua gangguan baik dari aktivitas manusia maupun akibat dari perubahan lingkungan. Untuk mendukung kegiatan monitoring kondisi habitat perairan laut dangkal maka diperlukan penyediaan informasi yang cepat dan akurat terkait kondisi sebaran ekosistem terumbu karang di suatu perairan.

Teknologi penginderaan jauh dapat dimanfaatkan untuk melakukan ekstraksi informasi habitat perairan laut dangkal karena memiliki kemampuan untuk perekaman obyek yang luas dan ketersediaan datanya dapat diakses dengan cukup mudah. Salah satu kendala dalam ekstraksi informasi terumbu karang adalah lokasi terumbu karang yang berada pada kolom air dimana kolom air ini menyerap sebagian besar energi gelombang elektromagnetik (LAPAN, 2014). Beberapa penelitian yang telah dilakukan terkait pemanfaatan data penginderaan jauh untuk informasi terumbu karang diantaranya Bano (2016) yang menggunakan citra Landsat 8 untuk memetakan terumbu karang di Teluk Tomini Bagian Kota Gorontalo. Budhiman dan Hasyim (2006) juga pernah memetakan sebaran terumbu karang di wilayah pesisir laut arafura menggunakan citra Landsat 7. Kemudian Setiawan dkk (2015) melakukan pemetaan terumbu karang di Perairan Pulau Tidung Kepulauan Seribu DKI Jakarta dengan menggunakan Citra Worldview-2. Beberapa metode kolom air yang sering digunakan dalam ekstraksi informasi terumbu karang diantaranya metode Lyzenga 1978, metode Lyzenga 1981 dan metode Lyzenga 2006. Pemanfaatan Citra Landsat 8 untuk Identifikasi Lamun pernah dilakukan oleh Setiawan dkk (2016) di Perairan Pulau Tidung Kepulauan Seribu DKI Jakarta.

Interpretasi secara visual habitat perairan perairan laut dangkal kaitannya dengan data penginderaan jauh memerlukan sebuah teknik penajaman citra yang nantinya mampu membedakan secara jelas habitat perairan laut dangkal yang terdiri dari terumbu karang, lamun, makroalga dan substrat dasar perairan dengan obyek lain di sekitarnya. Proses penajaman citra memerlukan waktu yang cukup lama karena harus melakukan pemilihan kanal-kanal dari citra untuk menghasilkan komposit 3 (tiga) kanal RGB terbaik dan informatif dalam identifikasi ekosistem terumbu karang. Salah satu metode penajaman citra yang bisa digunakan adalah Optimum Index Factor (OIF) dimana metode ini menerapkan perhitungan statistik dalam penentuan kombinasi 3 (tiga) kanal dalam citra yang mempunyai tampilan warna yang paling optimal dan informatif (Chavez et al., 1982). Semakin tinggi nilai OIF maka kombinasi kanal yang dipilih tersebut semakin memiliki banyak informasi (ditandai dengan nilai standar deviasi yang tinggi) dengan sedikit "duplikasi" (ditandai dengan nilai korelasi yang rendah antar kanal) sehingga masing-masing komposit 3 (tiga) kanal yang dipilih dapat dievaluasi efektivitas tampilannya. Penelitian menggunakan teknik OIF pernah dilakukan oleh Susanto $d k k$ 
(2011) untuk mengidentifikasi hutan mangrove dengan citra Landsat ETM+ di pesisir Batam. Manoppo dkk (2015) menggunakan metode OIF untuk mengidentifikasi sebaran mangrove dari SPOT 6 dan Landsat 8 di Pulau Lingayan. Kemudian Marini dkk (2015) melakukan identifikasi mangrove dengan teknik OIF di Pulau Subi Kecil menggunakan citra Landsat 8.

Pantai Pemuteran di Bali terkenal dengan kelandaian daerahnya dengan panjang garis pantai sekitar $6 \mathrm{Km}$ dan berlatar bukit-bukit dengan dominasi pohon kelapa dan pohon arena. Di lokasi pantai ini terkenal dengan pemandangan bawah laut yang telah banyak ditumbuhi oleh terumbu karang dan juga ribuan ikan dengan berbagai jenis ikan. Ikhsani dkk (2014) pernah melakukan penelitian tentang kajian kesesuaian ekosistem terumbu buatan Biorock sebagai zona wisata Diving dan Snorkeling di Pantai Pemuteran, Bali. Menurut Winarso dkk (2015) citra warna komposit RGB 432 untuk citra Landsat-8 adalah komposit yang paling informatif untuk interpretasi visual kenampakan substrat dasar penyusun ekosistem terumbu karang di Kepulauan Seribu menggunakan data Landsat 8. Penelitian ini bertujuan untuk menentukan kombinasi kanal yang paling optimal/terbaik dalam identifikasi habitat dasar perairan laut dangkal di Pantai Pemuteran, Bali berdasarkan citra SPOT 7 dan Landsat 8 dengan menggunakan metode OIF. Jumlah kanal citra yang digunakan sebanyak 4 (empat) kanal untuk citra SPOT 7 dan 7 (tujuh) kanal untuk citra Landsat 8 (mulai kanal 1 sampai dengan kanal 7).

\section{MATERI DAN METODE}

Penelitian ini dilakukan di Pantai Pemuteran, Bali dengan batasan koordinat $8^{\circ} 5^{\prime} 19.51^{\prime \prime}-8^{\circ} 9^{\prime} 17.4^{\prime \prime}$ LS dan 114 $32^{\prime} 54.84^{\prime \prime}-114^{\circ} 39^{\prime} 36.61^{\prime \prime}$ BT. Citra satelit yang digunakan adalah citra SPOT 7 akuisisi tanggal 11 April 2018 dan citra Landsat 8 Path 117/Row 066 akuisisi tanggal 14 April 2018. Tabel 1 merupakan perbandingan spesifikasi kanal citra SPOT 7 dan Landsat 8. Data informasi sebaran habitat dasar perairan laut dangkal berdasarkan hasil survei lapangan yang telah dilaksakan tanggal 7-13 April 2018 di Pantai Pemuteran, Bali yang terletak di Desa Pemuteran, Kecamatan Gerokgak, Kabupaten Buleleng, wilayah Bali Utara. Pantai ini berjarak sekitar 30 kilometer dari pusat kota Gilimanuk. Lokasi Penelitian ditampilkan pada Gambar 1.

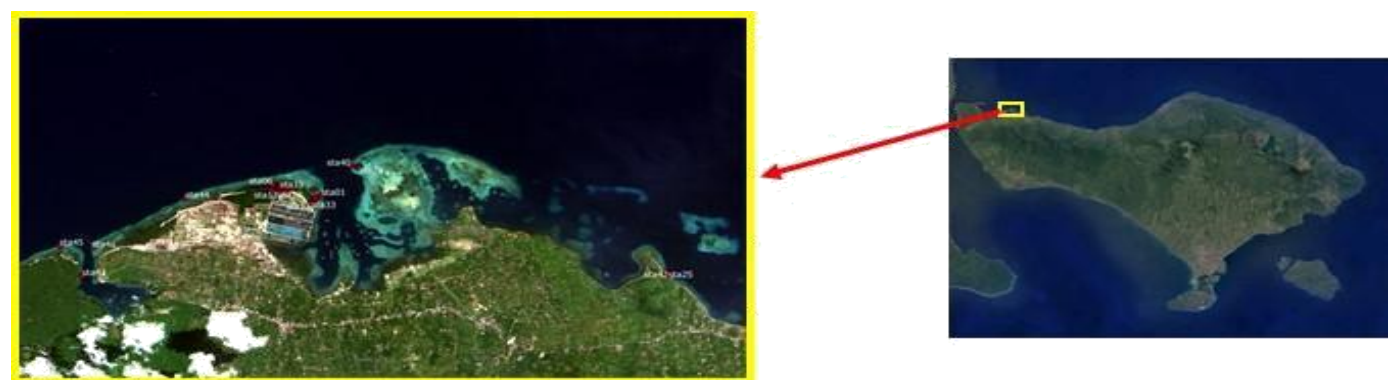

Gambar 1. Peta Lokasi Penelitian 
Satelit SPOT 7 telah diluncurkan pada tanggal 30 Juni 2014 yang lalu oleh perusahaan Airbus Defence \& Space dengan menggunakan roket pengangkut PSLV (Polar Satellite Launch Vehicle) C23. Spesifikasi satelit SPOT 7 hampir mirip dengan Satelit SPOT 6 sehingga banyak yang mengatakan Satelit SPOT 7 adalah kembaran dari Satelit SPOT 6 dengan usia yang lebih muda. Beberapa kemiripan di antaranya posisi satelit yang terpisah sejauh 180 derajat namun berada pada orbit yang sama, kemudian kedua satelit tersebut dapat merekam area seluas $60 \mathrm{Km} \times 60$ $\mathrm{Km}$ (pada keadaan nadir) dalam satu kali sapuan perekaman, serta data citra satelit hasil perekaman dalam moda multispektral (4 kanal) dengan resolusi spasial 6 meter (pada keadaan nadir) dan dalam moda pankromatik (1 kanal) dengan resolusi spasial 1.5 meter, dimana hal tersebut sama dengan citra yang dihasilkan oleh Satelit SPOT 6. Hal yang paling menarik dari satelit SPOT $5 / 6$ adalah kedua satelit tersebut merupakan generasi SPOT pertama yang mempunyai kanal spektral warna biru dimana kanal spektral biru berpotensi mempertegas batas tepi pantai, sedimentasi laut dan mendeteksi terumbu karang yang sulit dideteksi oleh kanal multispektral lainnya (Pustekdata LAPAN, 2014). Landsat 8 merupakan salah satu satelit generasi baru yang melanjutkan dan menyempurnakan misi satelit Landsat 7 ETM+ sebelumnya. Beberapa titik penyempurnaan diantaranya jumlah band, rentang spektrum gelombang elektromagnetik terendah yang dapat ditangkap sensor serta nilai bit dari tiap piksel data (Ayuindra, 2013 dalam Purwanto, 2014).

Tabel 1. Spesifikasi Citra SPOT 7 dan Landsat 8 (sumber: ASTRIUM, 2013)

\begin{tabular}{cll}
\hline SPOT 7 (Multispektral) & & LDCM OLI/TIRS Band \\
Kanal Spesifikasi $\mathrm{Mm}$ & Kanal & Spesifikasi $\mathrm{Mm}$
\end{tabular}

\begin{tabular}{lllll}
\hline & & & \multicolumn{2}{l}{ Coastal/Aer } \\
Kanal Blue & $0.450-0.520$ & Kanal 1 & osol & $0.433-0.453$ \\
Kanal Green & $0.530-0.590$ & Kanal 2 & Blue & $0.450-0.515$ \\
Kanal Red & $0.625-0.695$ & Kanal 3 & Green & $0.525-0.600$ \\
Kanal Near- & $0.760-0.890$ & Kanal 4 & Red & $0.630-0.680$ \\
& & Near & \\
& Kanal 5 & Infrared & $0.845-0.885$ \\
& Kanal 6 & SWIR 1 & $1.560-1.660$ \\
& Kanal 7 & SWIR 2 & $2.100-2.300$ \\
& Kanal 8 & Pan & $0.500-0.680$ \\
& Kanal 9 & Cirrus & $1.360-1.390$ \\
& & Kanal & TIRS 1 & $10.3-11.3$ \\
& & Kanal & TIRS 2 & $11.5-12.5$ \\
\hline
\end{tabular}


Identifikasi habitat dasar perairan laut dangkal dapat dilakukan dengan menggunakan kanal visible (sinar tampak) yang terdiri atas kanal biru dan kanal hijau (Suwargana, 2014). Berdasarkan Tabel 1 untuk kanal biru dan kanal hijau citra SPOT 7 terdapat pada kanal 1 dan kanal 2, sedangkan pada citra Landsat 8 untuk kanal biru dan hijau terdapat pada kanal 2 dan kanal $3 . \quad$ Untuk menentukan 3 (tiga) kanal terbaik dalam interpretasi obyek tertentu digunakan metode OIF yang telah dikembangkan oleh Chaves et al, 1982 dimana metode ini menggunakan nilai standar deviasi dan koefisien korelasi dari kombinasi 3 kanal citra yang digunakan. Pada penelitian ini menggunakan metode OIF untuk menentukan komposit RGB terbaik dari tiga kanal citra Landsat 8 untuk mengidentifikasi sebaran habitat dasar perairan laut dangkal di Pantai Pemuteran, Bali. Adapun formula OIF adalah sebagai berikut:

$$
O I F=\sum_{i=1}^{3} S D i / \sum_{j=1}^{3} A B S(C C j)
$$

Keterangan:

SDi = Standar Deviasi Kanal i

ABS = Nilai absolut dari koefisien korelasi

Untuk menentukan jumlah kombinasi kanal yang terbentuk pada citra SPOT 7 dan Landsat 8 digunakan persamaan sebagai berikut:

$$
\left(\begin{array}{l}
N \\
3
\end{array}\right)=\frac{N !}{(3 ! *(N-3) !)}
$$

Keterangan:

$\mathrm{N}=$ Jumlah kanal yang digunakan

Berdasarkan persamaan di atas maka jumlah kombinasi kanal yang mungkin untuk 4 (empat) kanal pada citra SPOT 7 adalah 4 kombinasi citra komposit, sedangkan jumlah kombinasi kanal yang mungkin untuk 7 kanal yang digunakan pada citra Landsat 8 adalah 35 kombinasi citra komposit.

\section{HASIL DAN PEMBAHASAN}

Sebagaimana telah dijelaskan pada bab sebelumnya perhitungan OIF pada citra SPOT 7 terbentuk 4 buah kombinasi kanal dan jumlah kombinasi kanal pada citra Landsat 8 sebanyak 35 buah. Perhitungan banyaknya kombinasi kanal ditampilkan pada Persamaan 3 dan Persamaan 4.

$$
\begin{aligned}
& \mathrm{C}_{3}^{4}=\frac{4 !}{(3 ! *(4-3) !)}=\frac{4 * 3 * 2 * 1}{(3 * 2 * 1) *(1)}=4 \\
& \mathrm{C}_{3}^{7}=\frac{7 !}{(3 ! *(7-3) !)}=\frac{7 * 6 * 5 * 4 * 3 * 2 * 1}{(3 * 2 * 1) *(4 * 3 * 2 * 1)}=35
\end{aligned}
$$


Setelah jumlah kombinasi diperoleh maka selanjutnya dilakukan perhitungan OIF untuk masing-masing kombinasi tiga kanal tersebut. Kombinasi komposit RGB yang memiliki nilai OIF tertinggi menunjukkan hasil kombinasi terbaik. Hasil perhitungan OIF dari 4 buah kombinasi komposit pada citra SPOT 7 ditampilkan pada Tabel 2, sedangkan hasil perhitungan OIF dari 35 buah kombinasi komposit pada citra Landsat 8 ditampilkan pada Tabel 3.

Tabel 2. Nilai OIF dan Peringkat Kombinasi Citra SPOT 7

\begin{tabular}{llllll}
\hline No & Kombinasi & $\sum \mathrm{Sd}$ & $\sum \mathrm{R}$ & OIF & Peringkat \\
\hline 1 & 123 & 186.476 & 2.48 & 75.19193548 & Rank 4 \\
2 & 124 & 139.945 & 1.028 & 136.1332685 & Rank3 \\
3 & 134 & 116.582 & 0.852 & 136.8333333 & Rank 2 \\
4 & 234 & 147.814 & 1.002 & 147.5189621 & Rank 1 \\
\hline
\end{tabular}

Hasil perhitungan OIF pada Tabel 2 menunjukkan kombinasi kanal 2 (hijau), kanal 3 (merah) dan kanal 4 (NIR) dari citra SPOT 7 memiliki nilai OIF tertinggi yaitu 147.5189621 (peringkat 1), sedangkan kombinasi kanal 1 (biru), kanal 2 (hijau) dan kanal 3 (hijau) memiliki nilai OIF terendah yaitu 75.19193548. Kombinasi kanal 2,3 dan 4 memiliki nilai standar deviasi yang tinggi dan nilai koefisien korelasi relatif rendah sehingga kombinasi kanal ini memiliki nilai OIF tertinggi, kemudian kombinasi kanal 1, 2, dan 3 meskipun memiliki total standar deviasi yang paling tinggi, akan tetapi nilai koefisien korelasinya sangat tinggi sehingga kombinasi kanal ini memiliki nilai OIF terendah. Pada Tabel 3 terlihat kombinasi kanal 2 (biru), kanal 4 (merah) dan kanal 6 (SWIR1) dari citra Landsat 8 memiliki nilai OIF tertinggi yaitu 1806.61029 (peringkat 1), sedangkan kombinasi kanal 1 (coastal), kanal 2 (biru) dan kanal 7 (SWIR2) memiliki nilai OIF terendah yaitu 930.8175621. Kombinasi kanal 2,4 dan 6 memiliki nilai standar deviasi yang tinggi dan nilai koefisien korelasi paling rendah sehingga kombinasi kanal ini memiliki nilai OIF tertinggi, kemudian kombinasi kanal 1,2, dan 7 memiliki total standar deviasi yang paling rendah dan nilai koefisien korelasinya relatif tinggi sehingga kombinasi kanal ini memiliki nilai OIF terendah.

Tabel 3. Nilai OIF dan Peringkat Kombinasi Citra Landsat 8

\begin{tabular}{llllll}
\hline No & Kombinasi & $\sum$ Sd & $\sum \mathrm{R}$ & OIF & Peringkat \\
\hline 1 & 123 & $2,817.156$ & 2.914 & 966.7659574 & Rank 32 \\
2 & 124 & $2,781.976$ & 2.768 & 1005.049133 & Rank 31 \\
3 & 125 & $2,812.154$ & 2.457 & 1144.547823 & Rank 21 \\
4 & 126 & $2,654.441$ & 2.468 & 1075.543355 & Rank 28
\end{tabular}




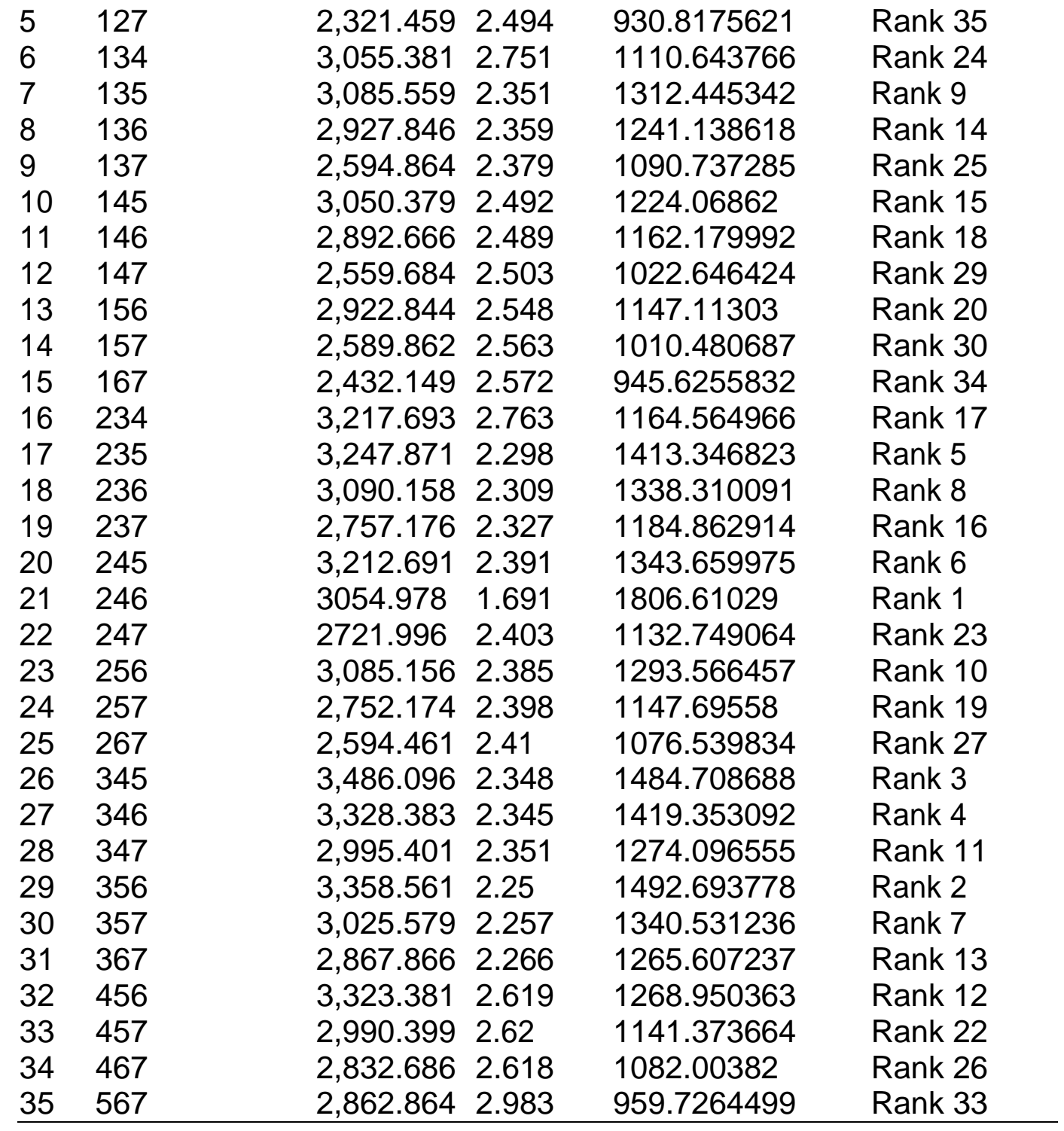

Semakin tinggi total standar deviasi dari 3 (tiga) kanal yang digunakan menunjukkan semakin banyak informasi yang dihasilkan, sedangkan semakin kecil total koefisien korelasi antara 2 (dua) kanal yang digunakan menunjukkan semakin sedikit duplikasi yang dihasilkan. Nilai OIF tertinggi merupakan hasil bagi antara total standar deviasi tertinggi dibagi dengan total koefisien korelasi terendah dari kombinasi kanal yang digunakan. Kombinasi kanal 1, 2 dan 7 pada Tabel 3 terlihat memiliki total standar deviasi yang paling tinggi, sedangkan nilai koefisian korelasinya relative tinggi sehingga dapat diartikan informasi yang dihasilkan dari kombinasi komposit kanalnya sangat sedikit diserta dengan banyaknya redundansi atau duplikasi informasi. Nilai standar deviasi dan koefisien korelasi diperoleh dengan cara membuat beberapa traning area pada obyek habitat dasar perairan laut dangkal. Pada Gambar 2 ditampilkan 
sebaran training area habitat dasar perairan laut dangkal yang terdiri dari terumbu karang, lamun, makroalga dan substat dasar di lokasi penelitian.

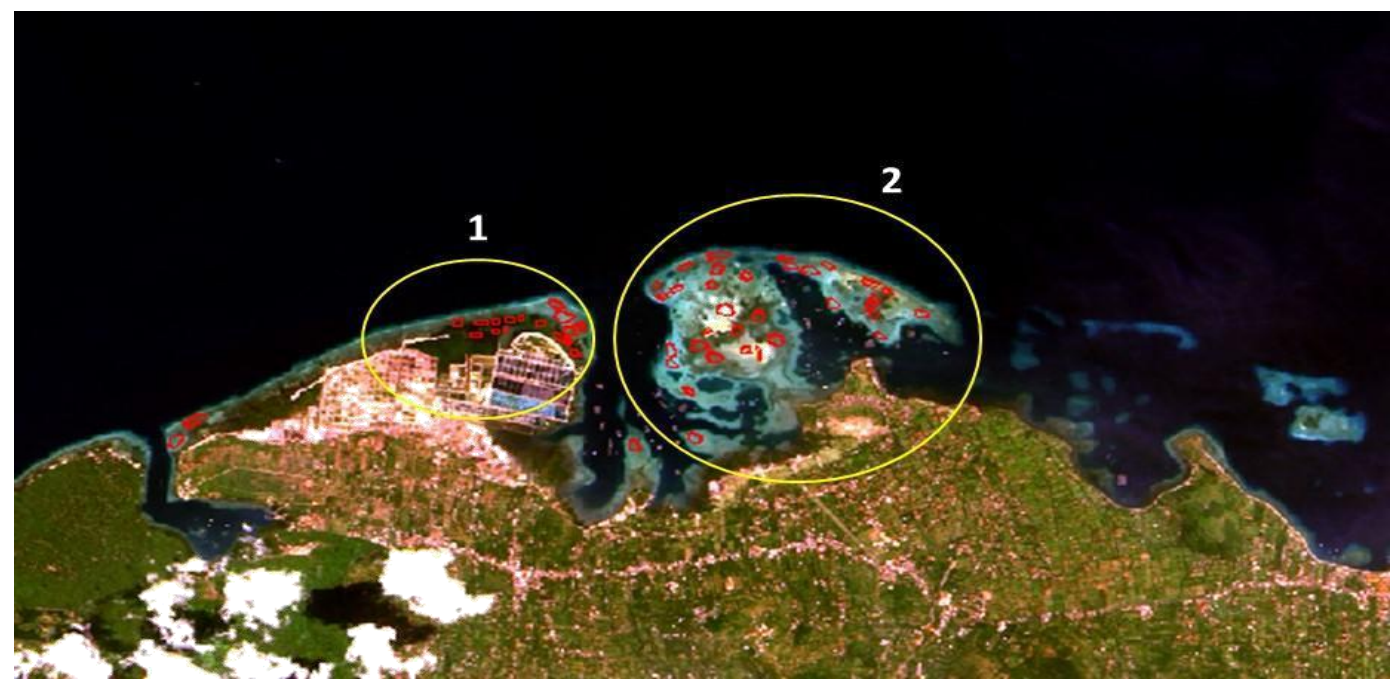

Gambar 2. Sebaran Training Sample

Total training sample yang diambil sekitar 50 buah yang tersebar di lokasi habitat dasar perairan laut dangkal. Berdasarkan hasil survei lapangan yang telah dilakukan, sebaran habitat dasar perairan laut dangkal banyak tersebar di bagian tengah dari lokasi penelitian. Pada area 1 didominasi oleh padang lamun dan makroalga, sedangkan untuk obyek terumbu karang dan substrat cenderung labih sedikit. Pada area 2 didominasi sebaran obyek substrat dan padang lamun, sedangkan obyek makroalga dan terumbu karang terlihat relatif lebih sedikit. Jika diambil peringkat terbaik lainnya dari masing-masing kombinasi komposit kanal pada citra SPOT 7 (Tabel 2) terlihat kombinasi band 1 (biru), band 3 (merah) dan band 4 (NIR) memiliki nilai OIF 136.8333333 (peringkat 2). Kombinasi band 1 (biru), band2 (hijau) dan band 4 (NIR) memiliki nilai OIF 136.1332685 (peringkat 3). Pada citra Landsat 8 untuk peringkat terbaik lainnya (Tabel 3) terlihat pada kombinasi kanal 3, 5 dan 6 memiliki nilai OIF 1492.693778 (peringkat 2), sedangkan kombinasi komposit kanal 3, 4 dan 5 memiliki nilai OIF sebesar 1484.708688693778 (peringkat 3).

Gambar 3 menunjukkan kombinasi komposit band 2, 3 dan 4 yang memiliki nilai OIF tertinggi dari citra SPOT 7 sehingga memberikan tampilan terbaik dan informatif dibandingkan kombinasi komposit lainnya. Dari kombinasi komposit band 234 ini dapat terbentuk sekitar 6 kombinasi komposit RGB diantaranya RGB 324, RGB 243, RGB 342, RGB 324, RGB 423 dan RGB 432. Dari keenam komposit RGB tersebut terlihat RGB 423 memberikan tampilan yang sangat baik dalam mengidentifikasi dan membedakan obyek habitat dasar perairan laut dangkal dengan obyek sekitarnya. Dengan komposit RGB 423 habitat dasar perairan laut dangkal ditampilkan dengan warna biru kehijauan, sedangkan daratan ditunjukan 
dengan warna merah gelap, dan laut terlihat warna biru tua. Pada Gambar 4 ditampilkan hasil komposit kombinasi 3 kanal dari citra Landsat 8 dimana total kombinasi yang dihasilkan sebanyak 35 buah.

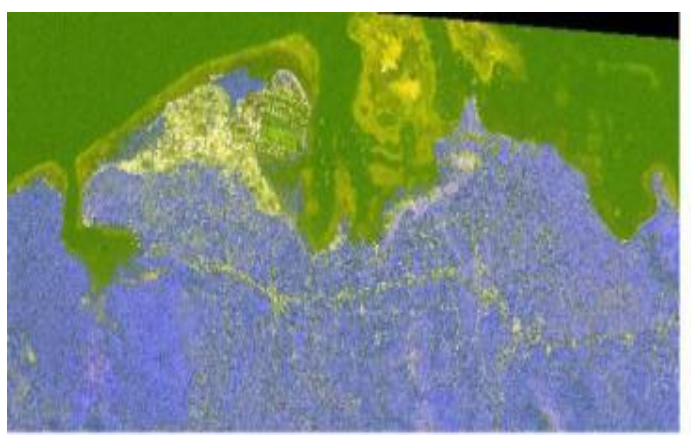

Komposit RGB 234

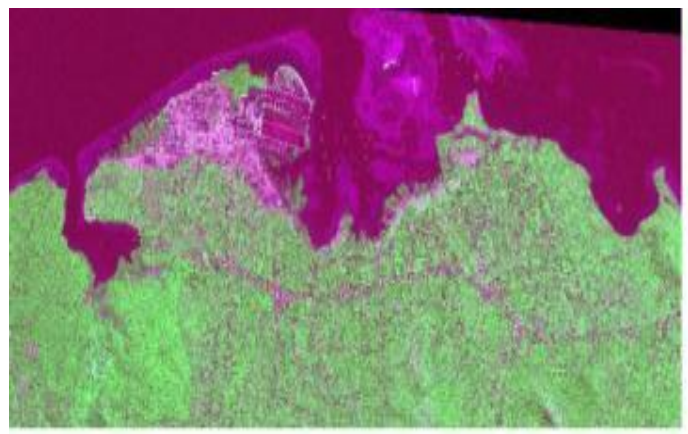

Komposit RGB 342

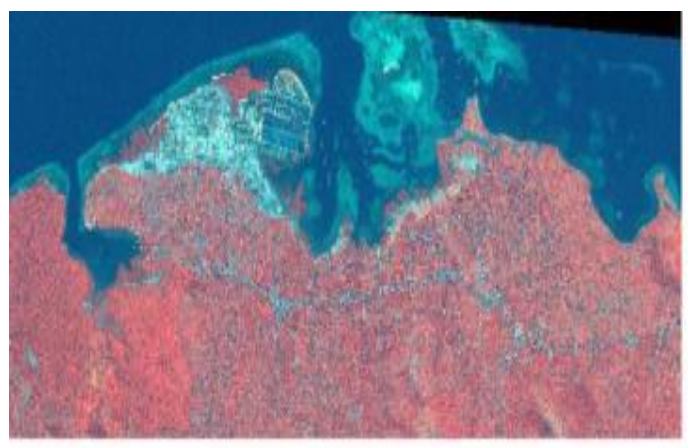

Komposit RGB 423

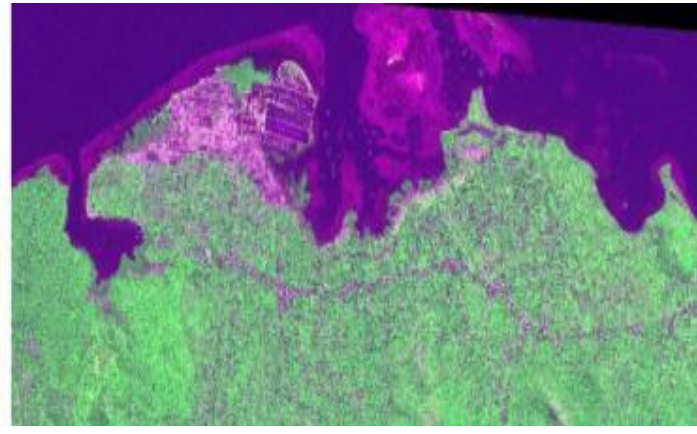

Komposit RGB 243

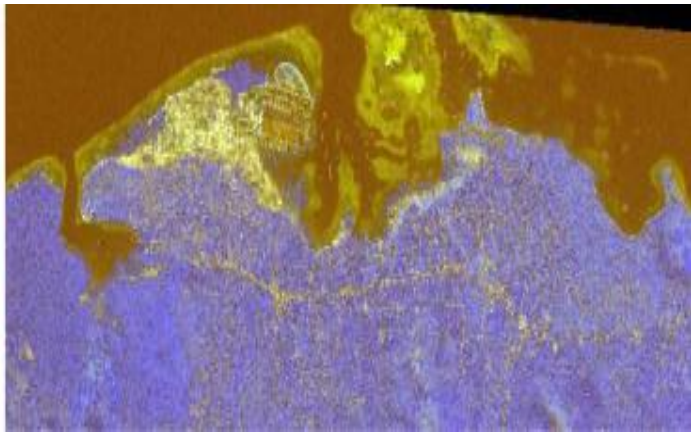

Komposit RGB 324

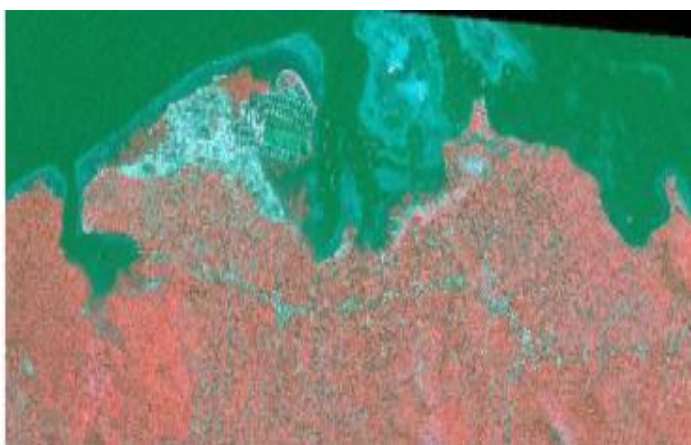

Komposit RGB 432

Gambar 3. Kombinasi komposit Kanal 2, 3 dan 4 yang memiliki nilai OIF tertinggi dari citra SPOT 7 

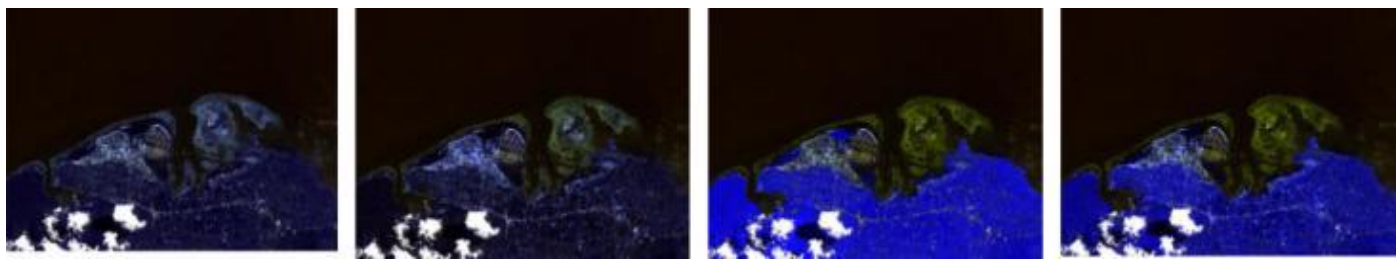

Komposit RGB

Komposit RGB

Komposit RGB 123 124

125

126
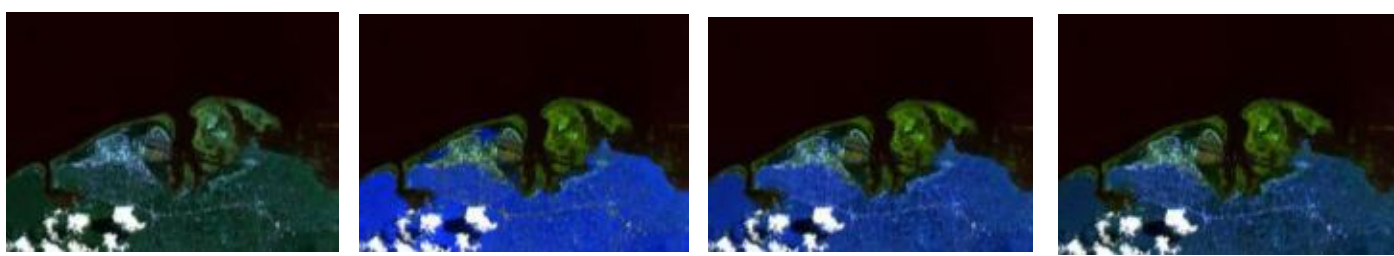

Komposit RGB 127 134

RGB

Komposit 135

RGB Komposit RGB 136
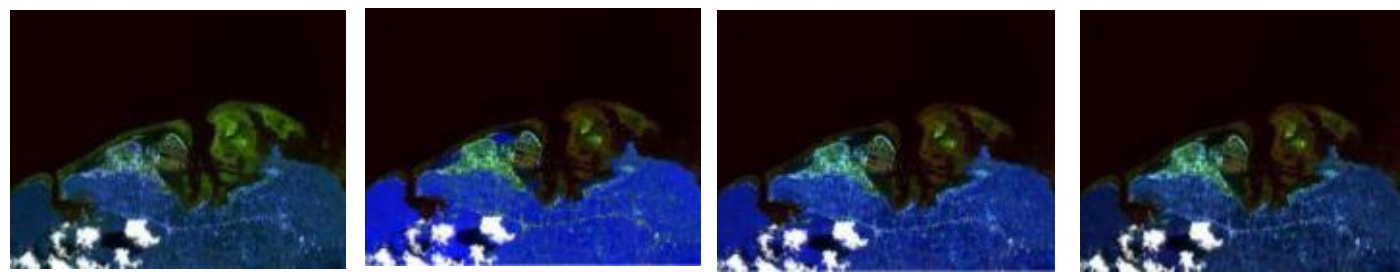

Komposit RGB 137

145

Komposit 146
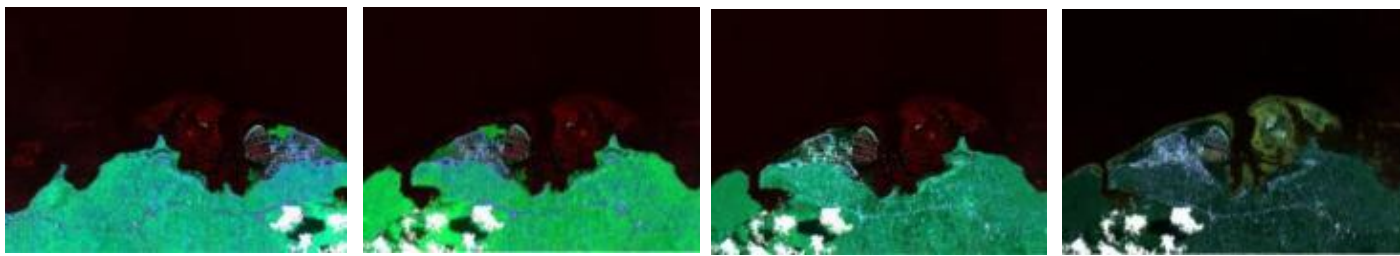

Komposit RGB 156 157

167

Komposit RGB 234
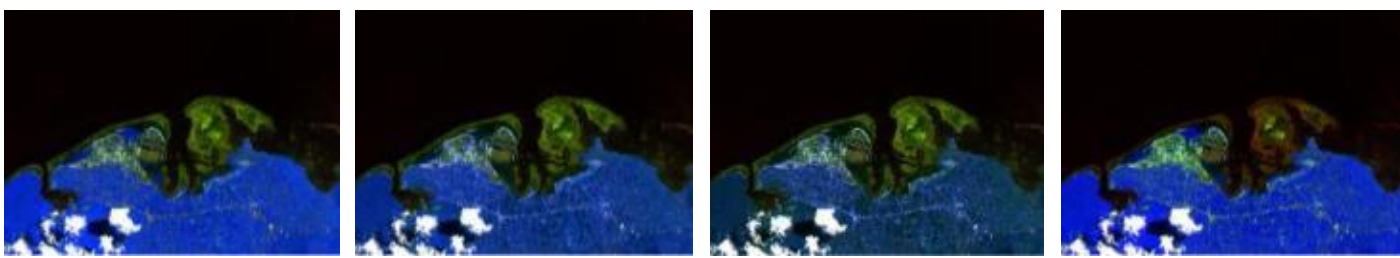

Komposit RGB

Komposit 235 236

RGB

Kompos 237
RGB

Komposit RGB 245 

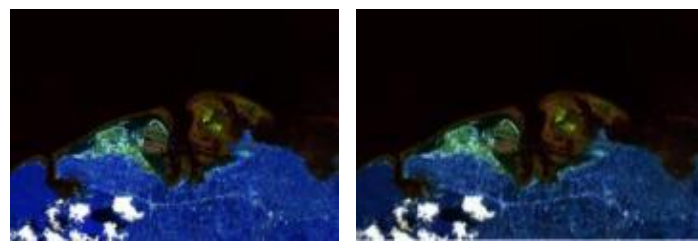

Komposit RGB 246

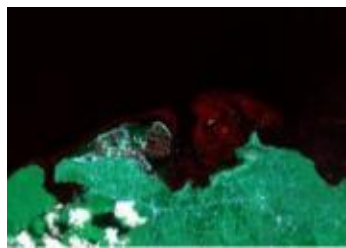

Komposit RGB 267

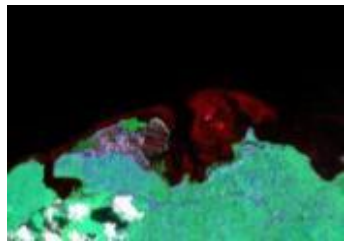

Komposit RGB 356

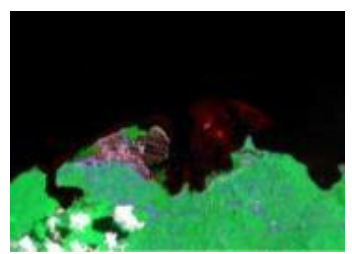

Komposit RGB 356
Komposit RGB 247

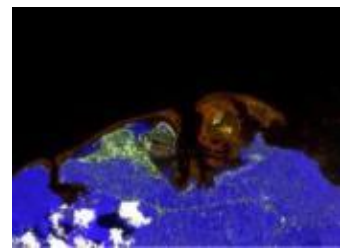

Komposit 345

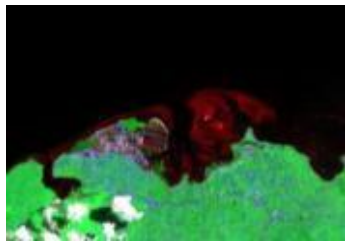

Komposit RGB 357

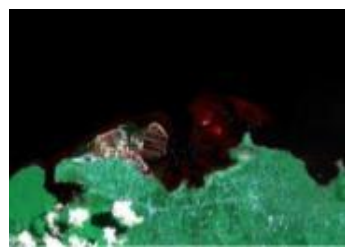

Komposit 357

RGB
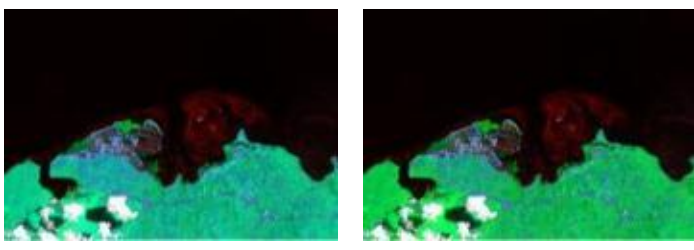

Komposit RGB 257
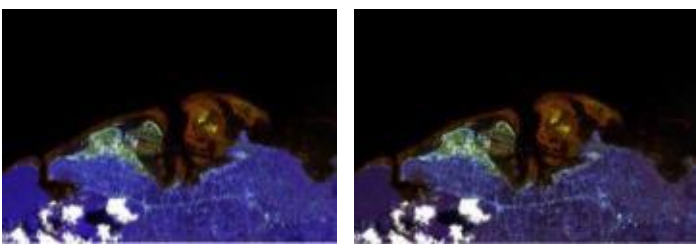

RGB

Komposit RGB 347
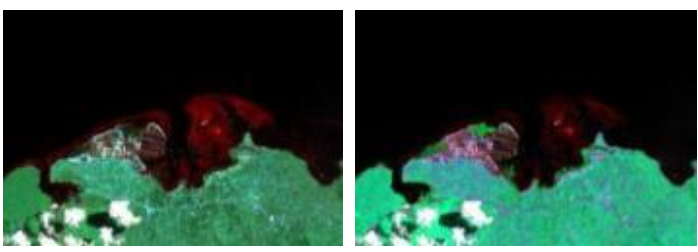

Komposit RGB 367

456

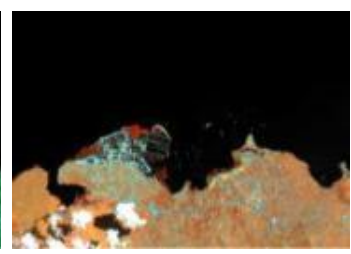

Komposit RGB 367

Gambar 4. Kenampakan Kombinasi 3 Kanal Komposit dari Citra Landsat 8

Tabel 4 merupakan koefisien korelasi antar band dari citra SPOT 7, kemudian hasil perhitungan merupakan koefisien korelasi antar band dari citra Landsat 8 ditampilkan juga pada Tabel 5. Berdasarkan hasil perhitungan total koefisien korelasi antar kanal 1, kanal 2 dan kanal 3 memiliki nilai koefisien korelasi paling tinggi untuk citra SPOT 7 , sedangkan total koefisien korelasi antar kanal 5, kanal 6 dan kanal 7 memiliki nilai koefisien korelasi paling tinggi untuk citra Landsat 8.nilai 
koefisien korelasi yang tinggi mengindikasilkan adanya duplikasi informasi yang tinggi dari kombinasi antar kanal tersebut.

Tabel 4. Koefisien Korelasi Antar Band Citra SPOT 7

\begin{tabular}{lllll}
\hline Kanal & Kanal 1 & Kanal 2 & Kanal 3 & Kanal 4 \\
\hline Kanal 1 & 1 & & & \\
Kanal 2 & 0.849 & 1 & & \\
Kanal 3 & 0.695 & 0.936 & 1 & 1 \\
Kanal 4 & 0.135 & 0.044 & 0.022 & \\
\hline
\end{tabular}

Tabel 5. Koefisien Korelasi Antar Band Citra Landsat 8

\begin{tabular}{|c|c|c|c|c|c|c|c|}
\hline Band & $\begin{array}{l}\text { Kanal } \\
1\end{array}$ & Kanal 2 & Kanal 3 & Kanal 4 & Kanal 5 & Kanal 6 & $\begin{array}{l}\text { Kanal } \\
7\end{array}$ \\
\hline Kanal 1 & 1 & & & & & & \\
\hline Kanal 2 & 0.988 & 1 & & & & & \\
\hline Kanal 3 & 0.948 & 0.978 & 1 & & & & \\
\hline Kanal 4 & 0.899 & 0.881 & 0.904 & 1 & & & \\
\hline Kanal 5 & 0.776 & 0.693 & 0.627 & 0.817 & 1 & & \\
\hline Kanal 6 & 0.78 & 0.7 & 0.631 & 0.81 & 0.992 & 1 & \\
\hline Kanal 7 & 0.794 & 0.712 & 0.637 & 0.81 & 0.993 & 0.998 & 1 \\
\hline
\end{tabular}

Gambar 5 menunjukkan kombinasi komposit band 2, 4 dan 6 yang memiliki nilai OIF tertinggi dari citra Landsat 8 sehingga memberikan tampilan terbaik dan informatif. Berdasarkan kombinasi komposit band 246 ini terbentuk sekitar 6 buah kombinasi komposit RGB diantaranya RGB 246, RGB 264, RGB 462, RGB 426, RGB 642 dan RGB 624. Dari keenam komposit RGB tersebut terlihat RGB 423 memberikan tampilan yang sangat baik dalam mengidentifikasi dan membedakan obyek habitat dasar perairan laut dangkal dengan obyek sekitarnya. Komposit RGB 642 menunjukkan habitat dasar perairan laut dangkal ditampilkan dengan warna biru-hijau kehijauan, sedangkan daratan ditunjukan dengan warna merah kecoklatan, dan laut terlihat warna gelap. 


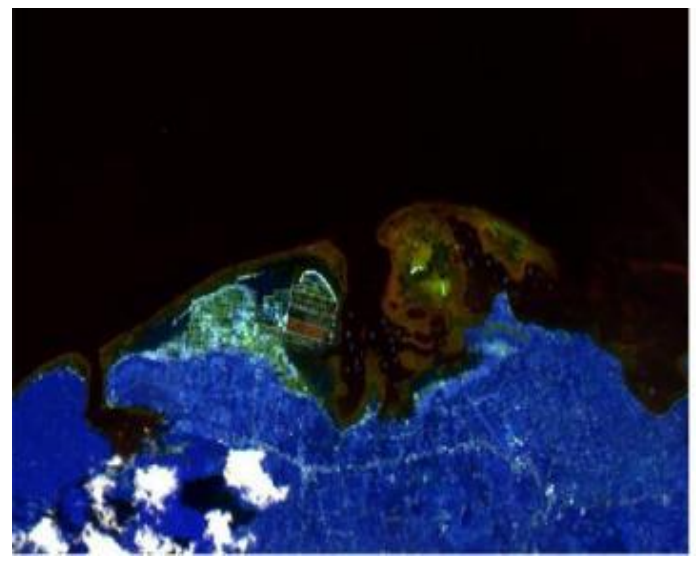

Komposit RGB 246

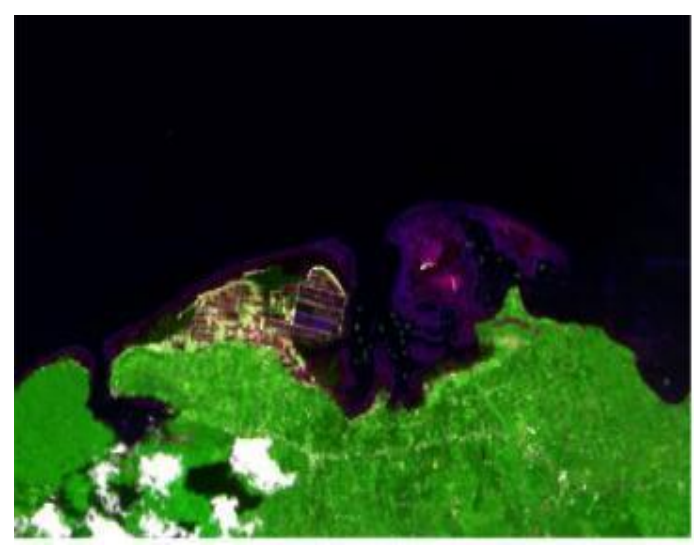

Komposit RGB 462

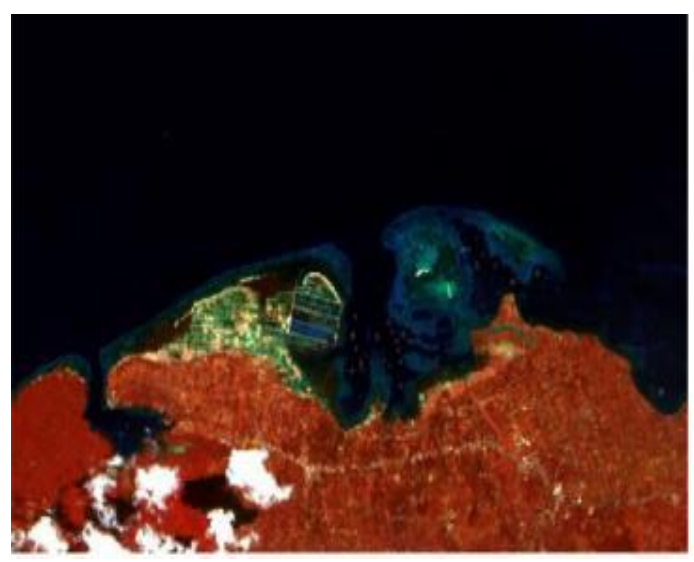

Komposit RGB 642

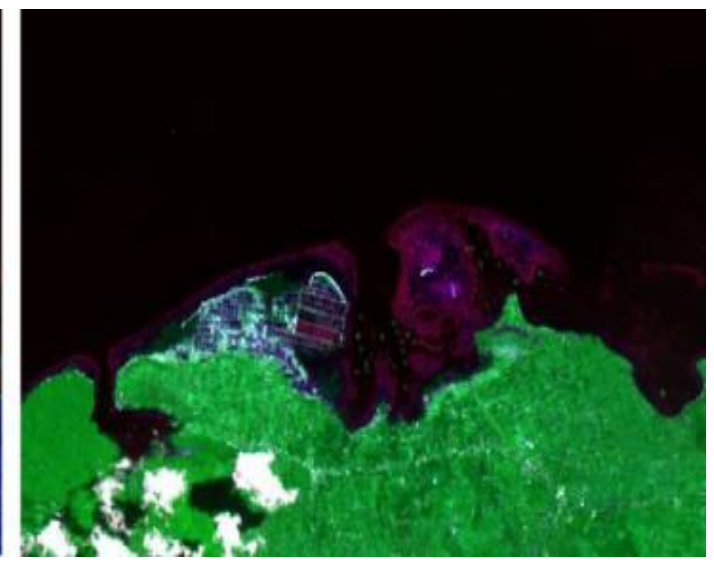

Komposit RGB 264

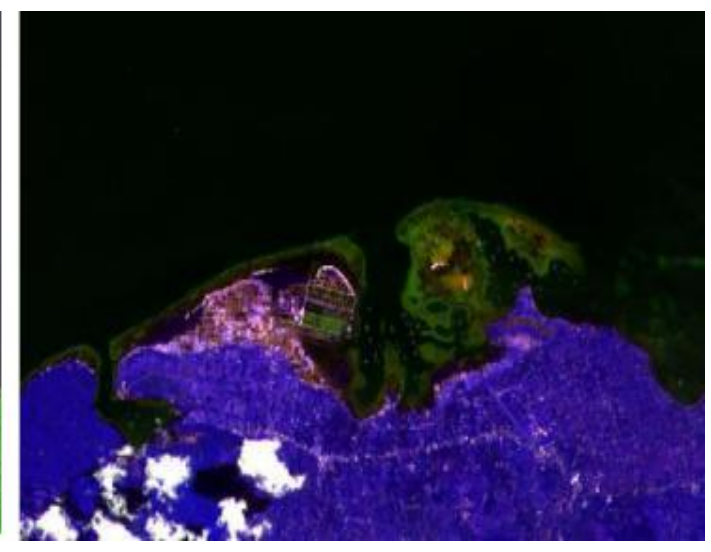

Komposit RGB 426

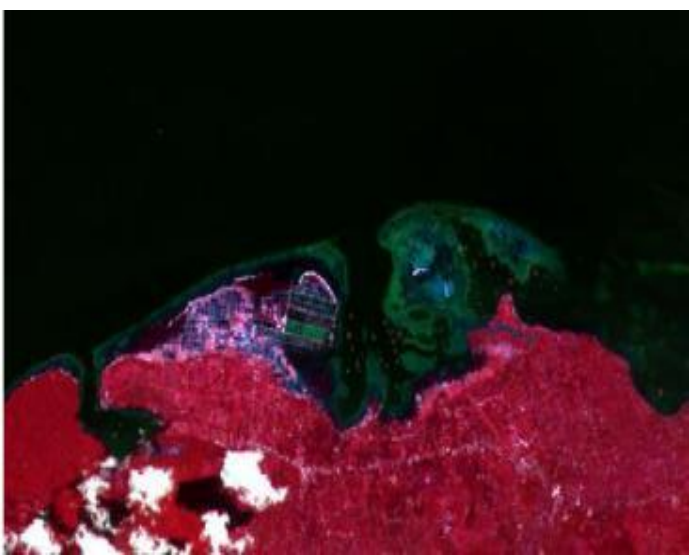

Komposit RGB 624

Gambar 5. Kombinasi Komposit Kanal 2, 4 dan 6 yang Memiliki Nilai OIF Tertinggi dari Citra Landsat 8 

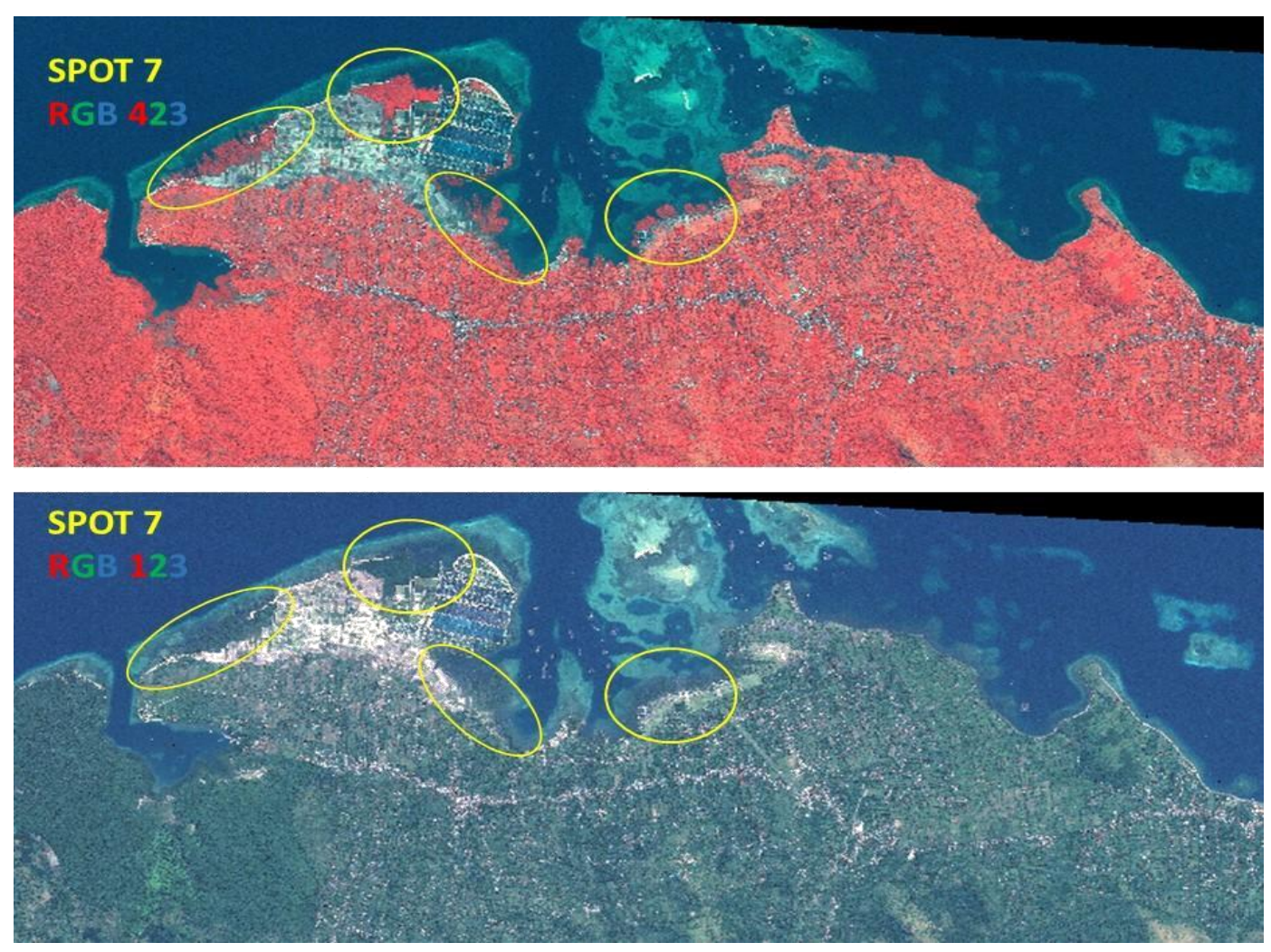

Gambar 6. Perbandingan Citra komposit RGB 423 dan RGB 123 (Natural Color) Citra SPOT 7

Pada Gambar 6 ditampilkan kenampakan hasil citra komposit RGB 423 dengan citra komposit RGB 123 (Natural Color) dari citra SPOT 7. Berdasarkan hasil perhitungan OIF komposit RGB 423 ini merupakan salah satu dari 3 (tiga) kombinasi kanal yang terbentuk dari komposit kanal 2, 3 dan 4 dimana komposit ini mempunyai nilai OIF tertinggi dari citra SPOT 7. Kenampakan citra komposit RGB 423 terlihat lebih jelas dan kontras dalam membedakan sebaran habitat dasar perairan laut dangkal dengan obyek sekitarnya dibandingkan dengan citra komposit RGB 123. Perbedaan yang paling signifikan terlihat pada obyek daratan dimana dengan citra komposit RGB 423 daratan terlihat berwarna kemerahan, sedangkan pada citra komposit RGB 123 obyek daratan terlihat berwarna kehijauan. Akan tetapi jika mengunakan citra komposit RGB 123 kemungkinan terjadinya salah interpretasi sebaran habitat dasar perairan laut dangkal relative lebih tinggi karena salah satu obyek habitat adalah ekosistem lamun dimana ekosistem ini termasuk vegetasi dalam air sehingga memantulkan warna kehijauan seperti obyek vegetasi yang ada di daratan pada umumnya. Setidaknya jika digunakan citra komposit RGB 423 dapat meminimalisir kesalahan awal dalam membedakan obyek habitat dasar perairan laut dangkal dengan non habitat dasar perairan laut dangkal (area yang dilingkari warna kuning). 

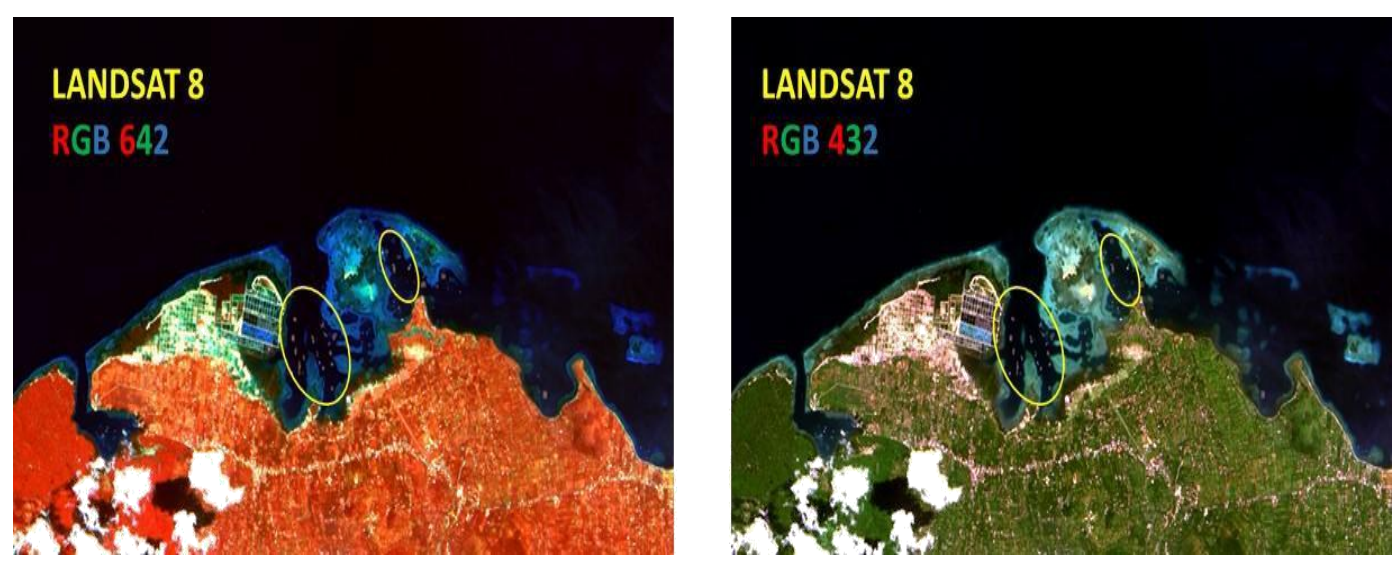

Gambar 7. Perbandingan Citra komposit RGB 642 dan RGB 432 (Natural Color) Citra Landsat 8

Gambar 7 merupakan perbandingan kenampakan citra komposit RGB 642 dengan RGB 432 (natural color) dari citra Landsat 8. Hasil kenampakan dari citra komposit RGB 642 sangat jelas membedakan sebaran habitat dasar perairan laut dangkal dengan obyek di sekitarnya dibanding citra komposit RGB 432. Akan tetapi penelitian yang dilakukan oleh Winarso $d k k$ (2015) menyebutkan untuk interpretasi visual kenampakan substrat dasar penyusun ekosistem terumbu karang dengan citra Landsat 8 dapat digunakan citra komposit RGB 432. Hasil kenampakan citra komposit RGB 432 dari Gambar 7 terutama pada area sebaran habitat dasar perairan laut dangkal terlihat lebih jelas dan kontras dibandingkan dengan hasil kenampakan citra komposit RGB 642 . Meskipun citra komposit RGB 642 memiliki nilai OIF tertinggi akan tetapi dalam interpretasi obyek sebaran habitat dasar perairan laut dangkal kenampakannya cenderung lebih gelap dan memerlukan teknik penajaman yang lebih detail lagi agar dapat dibedakan secara jelas dengan obyek laut di sekitarnya.

Penggunaan kanal NIR dan SWIR pada kedua hasil citra komposit RGB 423 (NIR+GREEN+RED) pada citra SPOT 7 dan RGB 642 (SWIR1+RED+BLUE) pada citra Landsat 8 dapat lebih menonjolkan obyek daratan sehingga memudahkan dalam identifikasi habitat dasar perairan laut dangkal. Penelitian yang dilakukan Susantoro et al., (2015) menggunakan perbandingan kanal NIR dan RED dan SWIR dan RED untuk meningkatkan ketajaman objek yang ada di laut. Hal ini juga dapat terlihat pada Gambar 7 (area yang dilingkari warna kuning) obyek keramba jaring apung (KJA) dapat diidentifikasi dengan menggunakan citra Landsat 8 dengan jelas. Telah diketahui bersama bahwa pola reflektansi obyek perairan semakin naik pada kanal hijau, kemudian akan berkurang dan bahkan mendekati nol pada kanal inframerah karena semua energi yang ada akan terserap. Sedangkan obyek daratan/tanah mempunyai kecenderungan pola pantulan yang semakin meningkat pada kanal inframerah tengah. Untuk penelitian terkait OIF yang selanjutnya, hendaknya dilakukan proses pemisahan wilayah daratan dan perairan terlebih dahulu, kemudian dilakukan overlay dengan sebaran habitat 
dasar perairan laut dangkal sehingga diperoleh nilai OIF hanya untuk area habitat dasar perairan laut dangkal. Selain itu juga perlu dilakukan pengolahan awal citra yang terdiri dari koreksi radiometrik, koreksi atmosferik dan koreksi kolom air untuk memperbaiki kualitas citra yang digunakan serta mengurangi beberapa efek gangguan yang ada baik di atmosfer maupun di kolom air.

\section{KESIMPULAN}

Metode OIF mampu membedakan habitat dasar perairan laut dangkal secara efektif. Kombinasi komposit kanal 2, 3 dan 4 memiliki nilai OIF tertinggi dari citra SPOT 7, sedangkan kombinasi kanal 2, 4 dan 6 memiliki nilai OIF tertinggi dari citra Landsat 8. Identifikasi habitat dasar perairan laut dangkal di Pantai Pemuteran, Bali dapat dilakukan dengan menggunakan citra komposit RGB 423 (SPOT 7), sedangkan pada citra Landsat 8 dapat digunakan citra komposit RGB 642. Kedua citra komposit tersebut merupakan salah satu hasil dari kombinasi 3 (tiga) kanal citra yang memiliki nilai OIF tertinggi sehingga mampu mengidentifikasi sebaran habitat dasar perairan laut dangkal informasi secara jelas dan mampu membedakan dengan obyek yang ada di sekitarnya.

\section{UCAPAN TERIMA KASIH}

Terima kasih penulis sampaikan kepada lbu Wikanti Asriningrum atas bimbingannya dan Kepala Pusat Pemanfaatan Inderaja LAPAN yang telah memfasilitasi penulis.

\section{DAFTAR PUSTAKA}

Astrium. 2013. SPOT 6 \& SPOT 7 Users Guide. ASTRIUM. Diunduh pada $30 \quad$ Mei $2018 \quad$ dari http://www.blackbridge.com/geomatics/upload/airbus/SP OT67\%20User\%20Guide.pdf )

Bano, V.S. 2016. Pemanfaatan Citra Penginderaan Jauh Untuk Pemetaan Terumbu Karang di Teluk Tomini Bagian Kota Gorontalo. Jurnal Bumi Indonesia, 5(3), 2016.

Budhiman, S., dan Hasyim, B. 2006. Pemetaan Sebaran Mangrove, Padang Lamun, Dan Terumbu Karang Menggunakan Data Penginderaan Jauh Di Wilayah Pesisir Laut Arafura. Prosiding PIT MAPIN XIV, Surabaya, Indonesia.

Chavez, P.S., Berlin, G.L., dan Sowers, L.B. 1982. Statistical method for selecting Landsat MSS ratios. Photographic Engineering, 8(1):1982. 
Dewi, E.S. 2006. Analisis Ekonomi Manfaat Ekosistem Terumbu Karang di Pulau Ternate Provinsi Maluku Utara. (Sekolah Pascasarjana Institut Pertanian Bogor), IPB (Bogor Agricultural University), Bogor.

Winarso, G., Setiawan, K.T., Marini, Y., dan Hartuti, M. 2015. Interpretasi Visual Kenampakan Substrat Dasar Penyusun Ekosistem Terumbu Karang di Kepulauan seribu Menggunakan Data Landsat 8. Buku Buka Rampai Pemanfaatan Penginderaan jauh untuk Wilayah Pesisir dan Laut. IPB Press: Bogor.

Ikhsani, N.R., Trianto, A., dan Irwani. 2014. Kajian Kesesuaian Ekosistem Terumbu Buatan Biorock Sebagai Zona Wisata Diving dan Snorkeling di Pantai Pemuteran, Bali. Marine Research, 3(4), 2014.

Manoppo, A., Anggraini, N., dan Marini, Y. 2015. Identifikasi Mangrove Dengan Metode Optimum Index Factor (OIF) Pada Data SPOT 6 dan Landsat 8 di Pulau Lingayan. Prosiding PIT MAPIN XX, Bogor, Indonesia.

Marini, Y., Manoppo, A., Anggraini, N., 2015. Teknik Penentuan Komposit Warna RGB untuk Identifikasi Mangrove di Pulau Subi Kecil Menggunakan Data Landsat 8. Buku Buka Rampai Mangrove: Citra Penginderaan Jauh dan Identifikasinya. IPB Press: Bogor.

Purwanto, A.D, Asriningrum, W, Winarso, G, Parwati, E. 2014. Analisis Sebaran dan Kerapatan Mangrove Menggunakan Citra Landsat 8 Di Segara Anakan, Cilacap. Prosiding Seminar Nasional Penginderaan Jauh LAPAN 2014, Bogor, Indonesia.

Pusfatja LAPAN. 2014. Pemanfaatan Data Penginderaan Jauh Untuk Ekstraksi Informasi Terumbu Karang: LAPAN.

PUSTEKDATA LAPAN. 2013. Spesifikasi Data SPOT-6 dan SPOT-7. Diakses pada 25 Mei 2018 dari http://pustekdata.lapan.go.id/ index.php/subblog/read/2014/2631/Spesifik asi-Data-Spot-6-danSpot-7/litbang-pengolahan-data.

Setiawan, K.T., Marini, Y., dan Winarso, G. 2015. Pemetaan Terumbu Karang di Perairan Pulau Tidung Kepulauan Seribu DKI Jakarta dengan Menggunakan Citra Worldview-2. Prosiding PIT MAPIN XX, Bogor, Indonesia.

Setiawan, K.T., Marini, Y., dan Constina, Y. 2016. Pemanfaatan Citra Landsat 8 untuk Identifikasi Lamun di Perairan Pulau Tidung Kepulauan Seribu DKI Jakarta. Prosiding Sinasja 2016, Jakarta, Indonesia. 
Setyawan, I.E., Siregar, V.P., Pramono, G.H., dan Yuwono, D.M. 2014. Pemetaan Profil Habitat Dasar Perairan Dangkal Berdasarkan Bentuk Topografi: Studi Kasus Pulau Panggang, Kepulauan Seribu Jakarta. Majalah IImiah Globe, 16(2), 2014.

Susanto., Asriningrum W. 2011. Penginderaan Jauh Dengan Nilai Indeks Faktor Untuk Identifikasi Mangrove di Batam (Studi Kasus Gugusan Pulau Jandaberhias). J Berita Dirgantara Vol. 12 No. 3: 104-109.

Susantoro, T.M., dan Wikantika, K. 2015. Pengolahan Data Landsat 8 Untuk Ekstraksi Objek Di Permukaan Laut. Jurnal IImiah Geomatika, 21 (2), 2015.

Suwargana, N. 2014. Analisis Citra Alos AVNIR-2 Untuk Pemetaan Terumbu Karang (Studi Kasus: Banyuputih, Kabupaten Situbondo). Prosiding SINASJA 2014, Bogor, Indonesia 